DOI: 10.33766/2524-0323.91.127-138

УДК 343.143

В. В. Навроцька,

кандидат юридичних наук, доцент, доцент кафедри кримінально-правових дисциплін Львівського державного університету внутрішніх справ (м. Львів, Україна) e-mail: superviranavr@gmail.com iDhttps://orcid.org/0000-0002-3407-7984

\title{
ПРАВО НА СВОБОДУ ВІД САМОВИКРИТТЯ, ВИКРИТТЯ ЧЛЕНІВ СІМ'̈̈ ЧИ БЛИЗЬКИХ РОДИЧІВ ЯК ОДНА ІЗ ПРОЦЕСУАЛЬНИХ ГАРАНТІЙ
}

У статті досліджено питання сфери права допитуваного не давати показань та пояснень щодо себе, членів сім'ї, близьких родичів; указано, що воно є максимально широким та не повинно обмежуватися якимись галузевими рамками. Доведено, що допитуваний має право відмовитися повідомляти інформацію, яка викриває його (членів його сім'ї або близьких родичів) не тільки в діяннях, заборонених кримінальним законом, але й таких, що тягнуть за собою інші види юридичної відповідальності. Указано, що така відмова можлива без пояснення причин самої відмови. Обгрунтовано, що при визначенні кола осіб, котрі підлягають звільненню від давання показань унаслідок близьких відносин, потрібно керуватися не тільки самим фактом родинних чи подружніх стосунків, але й особливим характером довірливих відносин між людьми. 3 огляду на це, запропоновано нову редакцію п.1 ч.1 ст. 3 КПК України. Наведено аргументи проти точки зору, згідно з якою відповіді на питання встановлюючого характеру повинні бути дані навіть у тому випадку, коли особа володіє свідоцьким імунітетом. Звернуто увагу на суперечність між положеннями ст. 18 КПК України та ст. 63 Конституції України. Із урахуванням наведеного запропоновано нову редакцію ст. 18 КПК Украӥни.

Ключові слова: процесуальна гарантія, свобода від самовикриття, близькі родичі, члени сім'ї, свідоцький імунітет.

Постановка проблеми. Украӥна, узявши курс на побудову демократичної, правової держави, приділяє значну увагу закріпленню (у тому числі й на конституційному рівні) основоположних принципів(засад), на яких грунтується механізм реалізації захисту прав та свобод. Інститут імунітетів є однією з ланок такого механізму. Імунітет - це один із правових засобів держави, завдяки якому держава надає виключне право суб'єктам, котрі посідають особливе місце (у міждержавних, державних та суспільних відносинах) та можуть не підпорядковуватися окремим загальним правилам.

Закріплення на законодавчому рівні та удосконалення інституту імунітетів (зокрема, і свідоцького імунітету) є кроком по зміцненню моральних та демократичних засад українського кримінального процесу, важливим засобом забезпечення процесуальних гарантій обгрунтованості законності залучення учасників кримінального судочинства до сфери цього судочинства, а також застосування до них належних правообмежень.

Аналіз останніх досліджень і публікацій. Стверджувати те, що право на свободу від самовикриття, викриття членів сім'ї та близьких родичів не було предметом

() Навроцька В. В., 2020 
наукових досліджень, звісно ж, не можна. Чимало аспектів зазначеного права та відповідної процесуальної гарантії свого часу аналізували Р. В. Бараннік, С. Бентам, А. Ф. Коні, М. С. Строгович, В. Т. Нор, М. М. Полянський, І. В. Смолькова, Б. Г. Розовський, О. Ю. Якимов та інші вчені. Проте чимало питань залишилися поза їхньою увагою чи є дискусійними. 3 огляду на це, існує необхідність нового детального аналізу зазначених положень.

Формулювання цілей. Метою статті є чітке визначення сфери права особи стосовно надання (відмови від надання) інформації відносно себе й інших близьких осіб, аналіз питання щодо можливого розширення категорії осіб, стосовно яких допитуваний у кримінальному судочинстві має право відмовитися давати показання та пояснення, а також формулювання на цій основі пропозицій по удосконаленню чинного законодавства.

Виклад основного матеріалу. У юридичній літературі справедливо зауважується, що свідоцький імунітет близького родича та члена сім'ї тісно пов'язаний із такими моральними категоріями, як совість та милосердя. Окрім того, даний вид свідоцького імунітету захищає також таємнищі приватного життя осіб.

Свобода особи в прийнятті рішення про давання показань викривального характеру проти близького родича та члена сім'ї грунтується на пануючих у суспільстві моральних уявленнях. Аморально вимагати від будь-кого, аби той викривав у вчиненні кримінального (чи будь-якого іншого) правопорушення близьку йому людину. У ч. 1 ст. 63 Конституції України передбачено, що особа не несе відповідальності за відмову давати показання або пояснення щодо себе, членів сім'ї чи близьких родичів, коло яких визначено законом.

А. Ф. Коні через це писав: «Заради цілей земного правосуддя не можна ослабити або ж порушити священні зв' язки, що пов' язують людей між собою. Закон оберігає ці почуття навіть при усвідомленні свідком винуватості підсудного чи наявності факторів, що його викривають. ...У людському погляді закону на таємничий голос крові чи подружньої прив' язаності полягає навіть визнання допустимості брехні, що в певних випадках білыш близька до внутрішньої правди життя, аніж об'єктивна та холодна істина» $[1 ; 2$, с. 52].

Непримиренним противником свідоцкого імунітету подружжя та близьких родичів виступав С. Бентам, зазначаючи, що: «...не слід відкривати сховище для злочинців, треба руйнувати будь-яку довіру між ними, якщо це можливо, навіть у надрах їхніх сімей. Якщо вони не зможуть знайти продажних покровителів поміж юристами, ні приховувачів у їхньому власному домі, то в чому ж полягає незручність? Цим вони будуть поставлені в необхідність дотримуватися законів та жити, як чесні люди» [3].

У праві відмовитися від давання показань стосовно близьких родичів та членів сім'ї знаходить свій прояв спосіб вирішення морального конфлікту, котрий виникає між інтересами особи та завданнями кримінального судочинства.

У теорії радянського кримінального процесу тривалий час панувала теза про перевагу інтересів досудового розслідування та правосудля в разі їх колізії з особистими інтересами та особистими таємницями. Обгрунтовуючи цю тезу, М. М. Полянський писав: «Радянське право, надаючи велике значення сімейним та шлюбним зв' язкам, не вважає, проте, за можливе жертвувати інтересами правосуддя на користь подружнім та родинним почуттям» [4, с. 93]. Аналогічний підхід поділяв також 
С. С. Подголін, вказуючи, що «... заради законної мети необхідно поступитися «суто моральною нормою» [5, с. 48].

Таким чином, окремі радянські дослідники моральні втрати, пов'язані 3 обов' язком (як його тоді розуміли) свідчити на шкоду своєму ближньому, взагалі не брали до уваги. Вони розглядали тільки однин аспект питання - інтереси встановлення істини в кримінальному судочинстві.

У ст. 385 КК України передбачено відповідальність свідка за відмову від давання показань. Згідно з ч. 2 цієї статті, не підлягає кримінальній відповідальності особа за відмову давати показання під час здійснення досудового розслідування або в суді щодо себе, а також членів їі сім'ї чи близьких родичів, коло яких визначається законом. Виникає питання: чи є право особи не давати показань щодо себе (а також інших осіб, коло яких визначено в законі) максимально широким, чи, можливо, воно обмежується певними галузевими рамками, адже в Конституції України не сказано, що особа вправі не свідчити щодо себе (та близьких родичів, членів сім'ї) тільки в рамках кримінального судочинства, оскільки давати показання можна і в адміністративному, і в цивільному, і в господарському процесі ?

Результати проведеного мною дослідження думок 56 респондентів (вік опитаних - 19-43 роки, стаж роботи яких за юридичною спеціальністю становив від 0 до 21 року) продемонстрували таке:

- 31 опитаних вважають, що до змісту інформащії, яку особа може відмовитись повідомляти в рамках використання права, наданого їй ч. 1 ст. 63 Конституції України та ст. 18 КПК України, належать дані, що свідчать про вчинення відповідною особою кримінального правопорушення чи іншого суспільно-небезпечного діяння (вчиненого неосудним чи особою, яка не досягла віку, з якого настає кримінальна відповідальність);

- 12 учасників анкетування зазначають, що сюди входять дані про вчинення особою кримінального чи адміністративного правопорушення;

- 7 осіб переконані, що до такої інформації належать відомості, які свідчать про вчинення особою порушення, за яке настає будь-який із передбачених законодавством видів відповідальності,

- ще 6 опитаних стверджують, що до змісту цієї інформащії відносяться дані, які свідчать про вчинення особою будь-якого правопорушення (не лише кримінального) чи іншого суспільно небезпечного діяння, а також відомості, що становлять будь-які інші обставини, які особа з будь-яких причин хоче зберегти в таємнищі (передовсім, це стосується таємнищі особистого життя). Незважаючи на те, що остання група респондентів найменша за чисельністю, я теж вважаю, що якраз остання із наведених позищій є такою, що грунтується на чинному законодавстві.

Слід зазначити, що аналізоване право на практищі зазвичай розуміють дуже вузько: як право не зізнаватися у вчиненні кримінального правопорушення (чи іншого суспільно небезпечного діяння). Наприклад, якщо особу обвинувачують у вчиненні однієї крадіжки, то у вчиненні іншої вона може не зізнаватися.

Однак особа може відмовлятися давати показання не тому, що сама вчинила кримінальне правопорушення, а тому, що виявилася причетною до нього дещо в іншій якості. 
1) До прикладу, футбольний уболівальник виявився втягнутим у масову бійку, розпочату «фанатами» на стадіоні. У результаті цієї бійки загинула людина. Безпосередній заподіювач смерті був одразу ж встановлений на основі даних відеоспостереження, хоча всіх учасників бійки допитали. Відмова свідка давати показання може бути зумовлена зовсім не тим, що він не бажає, аби його запідозрили у вчиненні злочину (адже вбивцю і так було викрито), а тим, що він побоюється позову з боку адміністрації стадіону про відшкодування шкоди за пошкодження майна стадіону. У даному випадку показання свідка, що аж ніяк не здатні заподіяти йому шкоду в кримінально-правовому сенсі, у майбутньому легко можуть обернутися проти нього в цивільно-правовому сенсі.

2) Можна дещо змінити ситуацію: припустімо, уболівальник сидів на протилежній трибуні і взагалі не брав участі в бійці, затіяній «фанатами». Проте разом із іншими свідками був викликаний слідчим задля розслідування провадження. На допиті він теж відмовився давати показання із посиланням на ст. 63 Конституції України та ст. 18 КПК України, однак його відмова була зумовлена тим, що під час футбольного матчу цей вболівальник мав би бути на робочому місці, але самовільно пішов з роботи, не бажаючи пропустити важливий матч. Звісно ж, подібне порушення трудової дисципліни є підставою для накладення на нього дисциплінарного стягнення, тому причиною відмови від давання показань у змодельованій ситуації може бути усвідомлення того, що факт перебування його в робочий час поза межами місця праці (зафіксований у протоколі допиту, за умови, що роботодавець про це дізнається), цілком може обернутися проти нього.

3) Не виключений також інший варіант: проїжджаючи повз стадіон, водій, невдало маневруючи, пошкодив чужу машину, що була припаркована поруч. Припустімо, факт знаходження його машини біля стадіону був встановлений (до прикладу, номер машини зафіксували камери відеоспостереження стадіону, хоча факт ДТП в об'єктив не потрапив). Відмова водія від давання показань може бути зумовлена тим, що йому доводиться приховувати одразу дві негативні обставини: а) факт заподіяння шкоди (цивільно-правовий делікт) та б) факт залишення місця ДТП. Причому обидва зазначених факти, згідно із законом, він не зобов' язаний визнавати. Тобто свідоцькі показання, що не можуть завдати йому шкоди в кримінально-правовому сенсі, запросто могли б обернутися проти нього в цивільно-правовому й адміністративно-правовому сенсі.

4) Небажання давати показання може бути обумовлене також причинами етичного, релігійного та соціального характеру. Припустімо, хтось спостерігав бійку футбольних фанатів, перебуваючи у квартирі особи протилежної статі. Це звичайно ж, не карається нормами права, але може засуджуватися з огляду на норми релігії, моралі тощо. Якщо така особа буде встановлена як свідок (припустімо, розповість знайомим, що спостерігала бійку, будучи поруч стадіону, а про це згодом від них стане відомо працівникам правоохоронних органів), то наступна відмова від давання показань може бути зумовлена тим, що факт присутності цього свідка в чужій квартирі, зафіксований у протоколі допиту, може запросто заподіяти шкоду його репутації (коли мова, до прикладу, іде про відому особу, публічного політика, одруженого чоловіка чи заміжню жінку тощо), адже в змодельованій ситуації сам лише 
факт знаходження в чужій квартирі може викликати нездоровий інтерес «жовтої» преси, сторонніх осіб тощо.

5) Можлива ситуація, коли людина й сама точно не впевнена, чи варто їй приховувати певну інформацію. До прикладу, уночі, у безлюдному провулку на перехожого було вчинено напад, і він був змушений захищатися. Незабаром йому стає відомо, що в тому ж районі одразу після вказаної події було виявлено мертве тіло невідомого з ознаками насильнищької смерті. Будучи викликаною на допит, особа сама може не знати, чи був загиблий одним із нападників (позаяк прикмет нападаючих вона не запам' ятала), i, відповідно, сама точно не впевнена, чи варто їй приховувати від працівників правоохоронних органів факт нічної події. А тому, не бажаючи ризикувати, вона відмовляється від давання показань.

Таким чином, коли особа вирішила скористатися належним їй правом на свободу від самовикриття (а також викриття членів сім'ї або близьких родичів), найчастіше їі головною метою є небажання скомпрометувати або викрити себе чи своїх близьких родичів у вчиненні якогось діяння.

У юридичній літературі висловлена точка зору (з якою я повністю погоджуюся - В. Н.), що поняття «викриття» у даному контексті охоплює те, що особа може відмовитися повідомляти інформацію, яка викриває іï, членів іï сім’ї або близьких родичів не тільки в заборонених кримінальним законом діяннях, але й таких, що тягнуть за собою інші види юридичної відповідальності [6, с. 88-89, 91-92].

Потрібно звернути увагу також на те, що вітчизняний законодавець демонструє неоднаковий підхід та по-різному вирішує питання щодо сфери права особи стосовно надання (відмови від надання) інформації відносно себе й інших близьких осіб. Зокрема, у ст. 18 КПК України 2012 р. (яка має назву «Свобода від самовикриття та право не свідчити проти [тут та далі - курсив мій - В. Н.] близьких родичів та членів сім'і») мова йде про те, що ніяка особа не може бути змушена «визнавати свою невинуватість у вчиненні кримінального правопорушення або примушена давати пояснення, показання, що можуть стати підставою дяя підозри, обвинувачення у вчиненні кримінального правопорушення. Кожна особа має право не говорити нічого з приводу підозри чи обвинувачення проти неї... Жодна особа не може бути змушена давати пояснення, показання, що можуть стати підставою для підозри, обвинувачення у вчиненні близькими родичами чи членами сім'ї кримінального правопорушення».

Виходячи із цього положення КПК України 2012 р., можна зробити висновок, згідно з яким законодавець розуміє свободу від самовикриття (а також викриття близьких родичів та членів сім'ї) дуже вузько: як право особи не зізнаватися у вчиненні нею самою (та іншими особами, про яких є пряма вказівка в законі) кримінального правопорушення.

Водночас, згідно зі ст. 63 Конституції України, «особа не несе відповідальності за відмову давати показання або пояснення щодо себе, членів сім'ї чи близьких родичів, коло яких визначається законом». Законодавець використав у конституційній нормі словосполучення «щодо себе» (а не «проти себе», як це має місце в КПК України). Аналіз вищенаведеної норми свідчить про те, що хто-небудь може відмовитися надавати інформацію:

а) яку можливо буде використано для формулювання підозри чи обвинувачення; 
б) яка може бути нейтральною (до прикладу, дані про місце народження, рівень своєї освіти, свій вік - за умови, що він не має значення для визначення питання про вік, з якого настає кримінальна відповідальність тощо);

б) яка, навпаки, позитивно характеризує людину, але яку вона з будь-яких причин (наприклад, унаслідок своєї скромності, сором' язливості тощо) не хоче оприлюднювати.

Таким чином, ст. 63 Конституції України як така, що не передбачає обов' язку доводити не тільки свою невинуватість, але й будь-які інші обставини у справі, повинна мати пріоритет над положенням ст. 18 КПК України 2012 р., позаяк:

1) вона надає білыш широкі гарантії (а відповідне положення КПК України 2012 р., навпаки, суперечить та істотно звужує зміст ст. 63 Конституції);

2) до того ж, Конституція (відповідно до ієрархічного колізійно-правового принципу) має перевагу над іншими нормативно-правовими актами (у тому числі й над положеннями КПК України) [7, с. 147; 8, с. 6].

А тому існує потреба викласти ст. 18 КПК України в такій редакції:

«Стаття 18. Свобода від надання пояснень та показань щодо себе, иленів сім'ї та близъких родичів

1. Жодна особа неможе бути примушена давати будь-які пояснення та показання щодо себе, у тому числі визнати свою винуватість у вчиненні кримінального чи будь-якого іншого правопорушення.

2. Кожен має право не повідомляти будь-якої інформації щодо себе, иленів сім'ї, близьких родичів, у будь-який момент відмовитися відповідати на запитання, а також бути негайно повідомленою про ці права.

3. Жодна особа не може бути примушена давати пояснення, показання щодо близьких родичів чи членами ї̈ сім'ï, у тому числі й тих, щуо можуть доводити вчинення ними кримінального чи іншого правопорушення.

Працівники органів, що ведуть кримінальний процес, перед допитом будь-якого учасника процесу повинні роз'яснити йому право не давати показання, що яким-небудь чином стосуються самого цього учасника кримінального судочинства чи його близьких родичів та членів сім'ї (передусім, це стосується показань, що можуть бути використані для доведення винуватості підозрюваного / обвинуваченого у вчиненні кримінального правопорушення чи будь-якого іншого суспільно-небезпечного діяння). Про роз'яснення зазначеного права слід обов' язково зробити відмітку в протоколі слідчої дії (чи в журналі судового засідання). Якщо це не буде зроблено, то показання мають бути визнані юридично нікчемними, втратити доказову силу.

Однак якщо особа була про все це попереджена і їй було роз' яснене положення ст. 63 Конституції України та ст. 18 КПК України, а допитуваний усе ж вирішив давати показання, то їх слід оцінювати в сукупності з іншими доказами за загальними правилами оцінки доказів.

У всіх випадках, коли особа, користуючись правом свідоцького імунітету, заявляє про відмову давати показання, це повинно бути зафіксовано у відповідному процесуальному документі (протоколі, журналі судового засідання).

У разі відмови від наданого законом імунітету для використання показань як доказів, необхідне дотримання трьох умов: а) особі має бути роз'яснено зміст наданого їй законом права; б) відмова повинна мати добровільний характер; в) відмова 
не повинна розглядатися як обставина, що викриває власника зазначеного права у вчиненні кримінального чи будь-якого іншого правопорушення.

Фіксація роз' яснення особі права на імунітет від давання показань чи пояснень щодо себе (та / чи визначеного в законі кола осіб) нерідко є єдиним способом визначення допустимості показань як джерела доказів. Якщо учасник процесу відмовився від свого права на імунітет, це тягне за собою обов'язок давати правдиві показання під загрозою кримінального покарання.

Щоб притягнути будь-кого до кримінальної відповідальності за відмову від давання показань, необхідно довести, що: а) особа володіла тією інформацію, яку від неї намагалися отримати; та б) що в неї не було законних підстав для відмови в даванні таких відомостей. Проте законодавець не зобов'язує допитуваного пояснювати, чому певна інформаціє є «проти неї » / чи «щодо неї» (а також стосовно ії близьких родичів чи членів сім'ї). Зрозуміло, абсолютно нелогічно вимагати, аби допитуваний розповідав про це працівникам правоохоронних органів та суду, а ті б уже потім вирішували, чи вправі він був не ділитися з ними такою інформацією.

Презумпія невинуватості тут діє безпосередньо: особа має право відмовитися надавати будь-які показання (причому без пояснення причин відмови). Пращівник же правоохоронного органу, котрий вважає, що законного права для відмови в неї не було, повинен довести це у встановленому законом порядку. Тобто, допитуваному достатньо заявити, що він не бажає давати показання з огляду на те, що вони можуть бути розцінені проти неї (ії близьких родичів, членів сім'ї) або ж будь-яким іншим чином стосуватися іï самої (та / чи зазначених осіб) [9, с. 336].

У юридичній літературі висловлена також точка зору, згідно з якою відповіді на питання встановлюючого характеру (прізвище, ім'я, по батькові, дата народження) повинні бути надані і в тому випадку, коли особа володіє свідоцьким імунітетом [10, с. 184]. Подібний підхід свого часу було відбито в рішенні Верховного Суду у справі «Ларрі Дадлі Хейбель проти суду шостого юридичного округу штату Невада». Суть розглядуваного конфлікту зводилася до того, що заявник відмовився представитися представнику поліції (котрий розслідував справу про розбійний напад). У цій справі було постановлене рішення, згідно з яким, незважаючи на те що Конституція США гарантує кожному громадянину право на відмову від давання показань, здатних заподіяти йому шкоду, однак якщо людина була зупинена поліщією «за обставин, що чітко вказують на те, що ця особа вчинила... злочин, вона повинна ідентифікувати себе на вимогу». На підставі цього рішення зараз відмова представитися американському поліцейському трактується як правопорушення [11, с. 247-248].

Проте з таким твердженням (про обов'язок за будь-яких умов повідомляти відомості установчого характеру працівникам правоохоронних органів) можна посперечатися. Б. Г. Розовський, навпаки, вважає (і я з таким твердженням повністю погоджуюся - В. Н.), що: «...допустимо протестувати проти будь-якого питання, аж до анкетних даних. Де гарантія, що людина, якій задали питання: «Ваше прізвище?» не почне розмірковувати таким чином: «Зараз відновлюється культ імператорської сім'ї. Про це пишуть у газетах, ідуть передачі по телебаченню. Вчора була розмова між конвоїрами, слідчий теж згадав царя в якомусь прислів'ї. Хто причетний до 
вбивства царя - точно не відомо. Може з'ясували, що серед убивць був мій найближчий родич. Ганьба на решту життя. Краще не називати своє прізвище. Повна дурнищя, але аналогія бездоганна» [11, с. 270].

Законодавцю також варто подумати й над можливим розширенням кола осіб, котрих зараз відносено до членів сім'ї та близьких родичі. Наразі, згідно 3 п. 1 ч. 1 ст. 3 КПК України 2012 р., до близьких родичів та членів сім'ї належать: чоловік, дружина, батько, мати, вітчим, мачуха, син, дочка, пасинок, падчерка, рідний брат, рідна сестра, дід, баба, прадід, прабаба, внук, внучка, правнук, правнучка, усиновлювач чи усиновлений; опікун чи піклувальник; особа, яка перебуває під опікою або піклуванням; а також особи, котрі спільно проживають, пов' язані спільним побутом і мають взаємні права та обов' язки, у тому числі особи, які спільно проживають, але не перебувають у шлюбі.

Притому слід звернути увагу на рішення Конституційного Суду України у справі про офіційне тлумачення терміна «член сім'ї». У згадуваному рішенні КСУ поділяє членів сім'ї на дві групи:

1) до першої групи належать: а) чоловік або дружина, б) а також прямі родичі діти і батьки;

2) до другої групи віднесені:а) близькі родичі (рідні брати, сестри, онуки, діді баба); б) та інші родичі (брати, сестри дружини / чоловіка; неповнорідні брати і сестри; зять, невістка; вітчим, мачуха; опікуни, піклувальники; пасинки, падчерки та інші [12].

Доцільно саме в такому плані розглядати поняття «члени сім'ї» 3 огляду на право кожного на свободу від викриття себе, членів сім'ї чи близьких родичів. Зокрема, варто розширити категорію таких осіб за рахунок: 1) невістки / зятя; 2) батьків чоловіка / дружини (свекра / свекрухи, тестя / тещі).

Окрім того, щодо вдосконалення закону при визначенні кола осіб, котрі підлягають звільненню від давання показань унаслідок близьких відносин з підозрюваним, обвинуваченим (чи іншими учасниками кримінального судочинства), необхідно керуватися не тільки самим фактом родинних чи подружніх стосунків, але й особливим характером довірливих відносин між людьми (наречені; особи, які раніше перебували в шлюбі).

Притому при визначенні поняття «наречених» слід виходити із положення абз. 2 ч.1 ст. 28 Сімейного кодексу України, згідно з яким особи, котрі подали заяву про реєстрацію шлюбу, вважаються нареченими [13].

Що ж стосується віднесення до кола близьких родичів осіб, які раніше перебували в шлюбі, то, як видається, наведений мною підхід цілком узгоджується із положеннями закону України «Про внесення змін до Кримінального та Кримінального процесуального кодексів з метою реалізації положень про запобігання насильству стосовно жінок і домашньому насильству та боротьбу з цими явищами» [14].

У зв' язку з цим п. 1 ч. 1 ст. 3 КПК України 2012 р. раджу викласти у наступній редакції:

«близькі родичі та члени сім'ї- чоловік, дружина, батько, мати, вітчим, мачуха, син, дочка, пасинок, падчерка, рідний брат, рідна сестра, дідусь, бабуся, прадідусь, прабабуся, онук, онучка, правнук, правнучка, усиновлювач чи усиновлений, опікун або піклувальник, особа, котра перебуває під опікою чи піклуванням, а також особи, які спільно проживають, пов'язані спільним побутом та мають взаемні права й обов' язки, у тому числі особи, які спільно проживають, 
але не перебувають у шиюбі; невістка / зять, батьки чоловіка / дружини; наречені, особи, які раніме перебували в шиюбі».

Висновки. Отже, на підставі вищевикладеного,

1) звернуто увагу на суперечність між положеннями ст. 18 КПК України 2012 p. (у якому законодавець розуміє свободу від самовикриття, а також викриття близьких родичів та членів сім'ї дуже вузько: як право особи не зізнаватися у вчиненні кримінального правопорушення) та ст. 63 Конституції України (як такої, що не передбачає обов' язку доводити не тільки свою невинуватість, але й будь-які інші обставини в провадженні);

2) обгрунтовано, що за наявності такої суперечності ст. 63 Конституції повинна мати перевагу над положенням ст. 18 КПК України 2012 р.

3 огляду на це, запропоновано нову редакцію ст. 18 КПК України:

«Стаття 18. Свобода від надання пояснень та показань щодо себе, членів сім'ї та близьких родичів

1. Жодна особа не може бути примушена давати будь-які пояснення та показання щзоо себе, у тому числі визнати свою винуватість у вчиненні кримінального чи будь-якого іншого правопорушення.

2. Кожен вправі не повідомляти будь-якої інформації щодо себе, членів сім'ї, близьких родичів, у будь-який момент відмовитися відповідати на запитання, а також бути негайно повідомиеною про изі права.

3. Жодна особа не може бути примушена давати пояснення, показання щодо близьких родичів чи членами ї̈ сім'ї, у тому числі й тих, щуо можуть доводити вчинення ними кримінального чи іншого правопорушення».

У продовження висновків:

3) наведено аргументи проти висловленоїв літературі точки зору, згідно з якою відповіді на питання встановлюючого характеру повинні бути дані і в тому випадку, коли особа володіє свідоцьким імунітетом;

4) зазначено, що задля удосконалення процесуального закону при визначенні кола осіб, що підлягають звільненню від давання показань унаслідок близьких відносин $з$ підозрюваним, обвинуваченим (чи іншими учасниками кримінального судочинства), необхідно керуватися не тільки самим фактом родинних чи подружніх стосунків, але й особливим характером довірливих відносин між людьми (наречені, особи, які раніше перебували в шлюбі). А тому слід включити до категорії таких осіб: а) невістку / зятя; б) батьків чоловіка / дружини (свекра / свекруху, тестя / тещу).

Через те п. 1 ч. 1 ст. 3 КПК України 2012 р. запропоновано викласти в наступній редакції: «...близькі родичі та члени сім'ї-чоловік, дружина, батько, мати, вітчим, мачуха, син, дочка, пасинок, падчерка, рідний брат, рідна сестра, дідусь, бабуся, прадідусь, прабабуся, онук, онучка, правнук, правнучка, усиновлювач чи усиновлении, опікун або піклувальник, особа, котра перебуває під опікою чи піклуванням, а також особи, які спільно проживають, пов'язані спільним побутом та мають взаємні права й обов'язки, у тому числі особи, які спільно проживають, але не перебувають у шлюбі; невістка/зять, батьки чоловіка/дружини; наречені, особи, які раніше перебували у шлюбі».

\section{Використані джерела:}

1. Кони А. Ф. Нравственные начала в уголовном процессе. URL: https://www.biblioonline.ru/viewer/nravstvennye-nachala-v-ugolovnom-processe-izbrannye-raboty-415159\#page/2. 
2. Кони А. Ф. Нравственные начала в уголовном процессе. Собр. соч. в 8 -ми т. Т. 4. Москва: Юридическая литература, 1967.

3. Бентам И. О судебных доказательствах. URL:https://cyberleninka.ru/article/n/osudebnyh-dokazatelstvah.

4. Полянский Н. Н. Доказательства в иностранном уголовном процессе. Москва: Юрид. изд-во МЮ СССР, 1947. 142 с.

5. Подголин Е. Е. О целях и средствах их достижения в следственной работе. Этика предварительного следствия. Волгоград: ВСШ МВД СССР, 1976. С. 44-48.

6. Бараннік Р. В. Право особи на свободу від самовикриття, викриття членів ії сім'ї чи близьких родичів у кримінальному процесі України: дис. ...к.ю.н.: 12.00 .09 /Запорізький юридичний інститут. Запоріжжя, 2002. 235 с.

7. Навроцька В. В. Суд над Ісусом Христом з позищій древньоіудейського та сучасного кримінального права й процесу. Київ: Видавничий дім «АртЕК», 2016. 224 с.

8. Баганець О. Новий кримінальний процесуальний кодекс порушує принщип верховенства права. Дзеркало тижня. 23 березня 2013 р. №11(108). С. 6.

9. Якимов О. Ю., Якимова С. С. Проблемы уголовной ответственности за отказ от дачи показаний. Противодействие преступности: уголовно-правовые, криминологические и уголовно-исполнительные аспекты. Материалы III Российского Конгресса уголовного права, состоявшегося 29-30 мая 2008 г. Москва, Проспект, 2008. С. 333-238.

10. Смолькова И. В. Проблемы охраняемой законом тайны в уголовном процессе: дисс. ...д-ра юрид. наук: 12.00 .09 /Иркутская государственная экономическая академия. Иркутск, 1998. 404 с.

11. Розовский Б. Г. Ненаучные заметки о некоторых научных проблемах уголовного процесса: Эссе. Луганск: РИО ЛАВД, 2004. 600 с.

12. Справа про офіційне тлумачення терміну «член сім'ї: Рішення Конституційного Суду Українивід З червня 1999 року №5-рп/99. URL:https:/ zakon.rada.gov.ua/laws/show/v005p710-99.

13. Сімейний кодекс України: Закон України від 10 січня 2002 p. №2947-III. URL:http:/ /zakon.rada.gov.ua/laws/show/2947-14/print.

14. Про внесення змін до Кримінального та Кримінального процесуального кодексів України з метою реалізації положень Конвенції Ради Європи про запобігання насильству стосовно жінок і домашньому насильству та боротьбу з цими явищами: Закон України від 6 грудня 2017 року № 2227-VIII. URL:http:/ / zakon.rada.gov.ua/laws/show/2227-19.

\section{References:}

1. Koni, A. F. Nravstvennyye nachala v ugolovnom protsesse. URL:https://www.biblioonline.ru/viewer/nravstvennye-nachala-v-ugolovnom-processe-izbrannye-raboty415159\#page/2. [in Russian].

2. Koni, A. F. (1967) Nravstvennyye nachala v ugolovnom protsesse. Moskva: Yuridicheskaya literatura. [in Russian].

3. Bentam, I. O. sudebnykh dokazatel'stvakh. URL:https://cyberleninka.ru/article/n/osudebnyh-dokazatelstvah. [in Russian].

4. Polyanskiy, N. N. (1947) Dokazatel'stva v inostrannom ugolovnom protsesse. Moskva: Yurid. izd-vo MYU SSSR. [in Russian].

5. Podgolin,Ye. Ye. (1976) O tselyakh i sredstvakh ikh dostizheniya v sledstvennoy rabote. Etika predvaritel'nogo sledstviya. Volgograd: VSSH MVD SSSR. [in Russian].

6. Barannik, R. V. (2002) Pravo osoby na svobodu vid samovykryttya, vykryttya chleniv yiyi sim"yi chy blyz'kykh rodychiv u kryminal'nomu protsesi. Candidate's thesis. [in Ukrainian]. 
7. Navrots'ka, V. V. (2016) Sud nad Isusom Khrystom z pozytsiy drevn'oiudeys'koho ta suchasnoho kryminal'noho prava y protsesu. Kyiv: Vydavnychyy dim «ArtEK». [in Ukrainian].

8. Bahanets', O. (2013) Novyy kryminal'nyy protsesual'nyy kodeks porushuye pryntsyp verkhovenstva prava. Dzerkalo tyzhnya - Mirror of the week, 11(108),6. [in Ukrainian].

9. Yakimov, O. Yu., Yakimova, S. S. (2008) Problemy ugolovnoy otvetstvennosti za otkaz ot dachi pokazaniy. Protivodeystviye prestupnosti: ugolovno-pravovyye, kriminologicheskiye i ugolovno-ispolnitel'nyye aspekty. Materialy III Rossiyskogo Kongressa ugolovnogo prava - Materials of the III Russian Congress of Criminal Law (May, 29-30 2008. Moskva: Prospekt, 333-238. [in Russian].

10. Smol'kova, I. V. (1998) Problemy okhranyayemoy zakonom tayny v ugolovnom protsesse. Doctor's thesis. [in Russian].

11. Rozovskiy, B. G. (2004) Nenauchnyye zametki o nekotorykh nauchnykh problemakh ugolovnogo protsessa. Lugansk: RIO LAVD. [in Russian].

12. Sprava pro ofitsiyne tlumachennya terminu «chlen sim"yi»: Rishennya Konstytutsiynoho Sudu Ukrayiny vid 3 chervnya 1999 roku №5-rp/99 (1999) N. p. URL:https://zakon.rada.gov. ua/laws/show/v005p710-99. [in Ukrainian].

13. Simeynyy kodeks Ukrayiny: Zakon Ukrayiny vid 10 sichnya 200 r. №2947-III (2002). N. p. URL:http://zakon.rada.gov.ua/laws/show/2947-14/ print. [in Ukrainian].

14. Pro vnesennya zmin do Kryminal'noho ta Kryminal'noho protsesual'noho kodeksiv Ukrayiny z metoyu realizatsiyi polozhen' Konventsiyi Rady Yevropy pro zapobihannya nasyl'stvu stosovno zhinok i domashn'omu nasyl'stvu ta borot'bu z tsymy yavyshchamy: Zakon Ukrayiny vid 6 hrudnya 2017 roku № 2227-VIII. (2017). N. p. URL:http:/ / zakon.rada.gov.ua/laws/show/222719. [in Ukrainian].

Стаття надіӥила до редколегії 02.08.2020

Навроцкая В. В., кандидат юридических наук, доцент, доцент кафедры уголовно-правовых дисциплин Львовского государственного университета внутренних дел (г. Львов, Украина)

\section{ПРАВО НА СВОБОДУ ОТ САМОРАЗОБЛАЧЕНИЯ, РАЗОБЛАЧЕНИЯ ЧЛЕНОВ СЕМЬИ ИЛИ БЛИЗКИХ РОДСТВЕННИКОВ КАК ОДНА ИЗ ПРОЦЕССУАЛЬНЬХ ГАРАНТИЙ}

В статье исследованы вопросы о праве допрашиваемого не давать показаний и объяснений относительно себя, членов семьи, близких родственников; указано, что оно является максимально широким и не может ограничиваться определенными отраслевыми рамками. Доказано, что допрашиваемый вправе отказаться сообщать информацию, разоблачающую его (членов его семьи либо близких родственников) не только касательно деяний, запрещенных уголовным законом, но и влекущих за собой иные виды юридической ответственности. Указано, что такой отказ возможен без объяснения причин самого отказа. Обосновано, что при определении круга лиц, подлежащих освобождению от дачи показаний в результате близких отношений, нужно руководствоваться не только самим фактом родственных или супружеских отношений, но и особым характером доверительных отношений между людьми. Учитывая это, предложена новая редакция п. 1 ч. 1 ст. 3 УПК Украины. Приведены аргументы против точки зрения, согласно которой ответы на вопросы устанавливающего характера должны быть даны даже в том случае, когда лищо 
владеет свидетельским иммунитетом. Обращено внимание на противоречие между положениями ст. 18 УПК Украины и ст. 63 Конституции Украины. С учетом этого предложена новая редакция ст. 18 УПК Украины.

Ключевые слова: процессуальная гарантия, свобода от саморазоблачения, близкие родственники, члены семьи, свидетельский иммунитет.

\section{Navrotska V., Candidate of Law, Associate Professor, Associate Professor of the Department of criminal-law disciplines Lviv State University of Internal Affairs (Lviv, Ukraine)}

\section{THE RIGHT TO FREEDOM FROM SELF-DISCLOSURE, EXPOSING FAMILY MEMBERS OR CLOSE RELATIVES AS ONE OF THE PROCEDURAL GUARANTEES}

It is proved that the right of a person not to testify about himself/herself, family members, immediate relatives is as wide as possible and cannot be restricted by a certain branch frames. A person has the right to refuse to notify information that discloses him/her (his / her family members or immediate relatives) not only to criminal acts prohibited by criminal law, but also to those which entail other types of legal liability. Besides, a person has the right to refuse to give testimony about any data concerning himself/ herself (his / her immediate relatives or family members). Moreover, such a refusal can occur without explaining the reasons of it.

It is proved that in determining the extent of persons to be released from testimony due to close relations with the suspect/accused (or other criminal proceedings participants) is necessary to be guided not only by the fact of family or marital relations, but also by a special nature of trusting relations between them (brides, previously married). The arguments in favor of the statement under which the following persons should be included in this category are given: a) daughter-in-law / sonin-law, b) husband / wife parents (father-in-law /mother-in-law). That's why, a new revision of Clause 1 of Part 1 of Article 3 of the CPC of Ukraine 2012 is suggested.

The contradiction between the provisions of Article 18 of the CPC of Ukraine 2012 (in which the freedom from self-disclosure, as well as the disclosure of immediate relatives and family members the legislator understands narrowly: as the right of a person not to confess to committing a crime) and Article 63 of the Constitution of Ukraine (which does not imply an obligation to prove not only his/her innocence, but any other case in fact) is emphasized. It is substantiated that, within this contradiction, Article 63 of the Constitution of Ukraine should precede the provision of Article 18 of the CPC of Ukraine.

The article also presents arguments against the point of view expressed in the literature, under which the answer to ascertaining questions should be given even when a person has witness immunity. munity.

Keywords: freedom from self-disclosure, immediate relatives, family members, witness im- 